\title{
USP6 Gene
}

National Cancer Institute

\section{Source}

National Cancer Institute. USP6 Gene. NCI Thesaurus. Code C24892.

This gene is involved in the regulation of cellular ubiquitination. It also plays a role in promoting the recycling of endocytic vesicles to the plasma membrane. 